УДК 632.7:633.17(477.41)

(C) 2017

Іванова К. О., аспірант

(науковий керівник - доктор сільськогосподарських наук, професор М. М. Доля)

Національний університет біоресурсів і природокористування України

\title{
ФЕНОЛОГІЯ І ОСОБЛИВОСТІ ПОШИРЕННЯ ШКІДНИКІВ СОРГО В ЛІСОСТЕПУ УКРАЇНИ
}

\section{Рецензент - кандидат сільськогосподарських наук Л. П. Ющенко}

У статті наведені особливості формувань сучасної структури ентомокомплексу сорго. Виявлені домінуючі та найбільш шкідливі види комах на посівах сорго. Уточнена біологія та фенологія основних шкідників сорго, шзо спостерігались у зоні досліджень. Проаналізовано сучасний стан $і$ перспективи впровадження в рослинництві новітніх технологій захисту сорго в Лісостепу. Оиінені строки і період розмноження та поширення окремих видів фітофагів $i$ ï шкідливості на сорго. Визначені показники стійкості гібридів сорго до комплексу шкідливих видів комах Лicocmenу Украӥни.

Ключові слова: сорго зернове, фітофаги, попеличі, стебловий кукурудзяний метелик, підгризаючі совки, структура ентомокомплексу, фенологія.

Постановка проблеми. В сучасних умовах ведення сільського господарства, раціональне використання природних ресурсів пов'язане зі створенням і освоєнням моделі стійкого розвитку рослинництва. Так, за достовірної зміни клімату в найближчі роки, що впливає на ефективність сучасного землеробства. Важливим є оцінка наслідків і причин порушень саморегуляції агроценозів, зокрема під час вирощування сорго $[1,4,9]$. Головним чином під час вирощування порівняно стійких польових культур. Доцільно відмітити, що сорго одна 3 найбільш жаростійких та посухостійких культур у світовому землеробстві. Дослідження ентомокомплексу сорго актуальне в різних типах сучасних сівозмін, особливо в разі застосування ресурсо- і енергозберігаючих технологій захисту рослин.

Аналіз основних досліджень i публікацій, у яких започатковано розв'язання проблеми. Світовий попит на зерно сорго зростає, так відповідно до прогнозу, до 2050 року чисельність населення зросте понад 9 мільярдів людей, тому і першочерговим $є$ питання необхідності кількісного і якісного продовольчого забезпечення. При цьому, забезпечення своєчасного і високоякісного захисту посівів сільськогосподарських культур і зокрема від шкідників із екологічно безпечними системами заслуговує особливої уваги. Нагальним є і конт- роль особливості формування стійких популяцій шкідливих організмів. У зв'язку із цим захист сорго повинен бути комплексний, на основі біології та фенології основних фітофагів, що дає можливість оптимізувати захисні заходи від основних видів шкідників.

Метою досліджень було уточнити структуру та фенологію окремих видів ентомокомплексу сорго в Лісостепу України.

Матеріали і методи досліджень. Досліди проводили в базовому господарстві Інститут біоенергетичних культур і цукрових буряків, полігоні виставково-інноваційного центру НААН (с. Ксаверівка-2, Васильківський район, Київська область).

Спостереження виконані за загальноприйнятими та спеціалізованими методиками Левін Н. А., 1969; Поляков І. Я., 1975; Григоренко В. П., 1981; Доспехов Б. О., 1985; Омелюта В. П., 1986; Шапіро І. Д., 1986; Федоренко В. П., 1997; Трибель С. О. та ін., 2001; Андрійчук В. Г., 2002 Моніторинг шкідників сільськогосподарських культур: підручник / [Довгань С. В., Доля М. М., Мороз М. С., Борзих О. І., Ющенко Л. П.]. - К.: Агроосвіта, 2014. -279 c.

Результати досліджень. У 2014-2016 рр. спостерігалися достовірні коливання погоди, що свідчить про важливість оцінки стійкості як до посухи, так і фітофагів сорго, що використовується для харчування і на корм тваринам та інші цілі. Встановлено, що зміни погодних умов супроводжуються і масовим поширенням основних видів шкідників у нових структурах ентомокомплексу сорго. Це свідчить про те, що уточнення видового складу комах-фітофагів, пошук оптимальних агротехнічних прийомів вирощування сорго, а також високоефективне використання сучасних інсектицидів набуває особливої актуальності, так як сприяє збільшенню виробництва високоякісного зерна цієї культури. Водночас моніторинг фітосанітарного стану посівів сільськогосподарських культур, зокрема сорго, $\epsilon$ першочерговим завданням, а уточнення феноло- 


\section{СТОРІНКА МОЛОДОГО ВЧЕНОГО}

гії основних видів фітофагів сорго є нагальним як у довготривалих ротаціях польових культур, так і на щорічно розширених посівних площах сорго в регіоні досліджень $[2,5]$.

У роки спостережень на посівах сорго виявлені основні види шкідників, що пошкоджували до $37 \%$ рослин районованих та перспективних гібридів цієї культури. Так, звичайна злакова попелиця (Schisaphis graminum Rond) спостерігалась 3 підвищеною чисельністю, а кількість i шкодочинність окремих грунтових шкідників, зокрема підгризаючих совок, озимої (Agrotis segetum) достовірно коливалась по роках спостережень. Посіви сорго заселяв і стебловий (кукурудзяний) метелик (Ostrinia nubilalis Hb.), зокрема на пізньостиглих гібридах, цей фітофаг пошкоджував до $23 \%$ рослин.

Відмічено, що поширення фітофагів на посівах сорго, регулюється не тільки рослиноюгосподарем, але і фізіологічними показниками строками достигання різних гібридів.

Так, Юкі - ранній гібрид зернового сорго, колір зерна - червоний. Заселявся комплексом фітофагів, головним чином на перших етапах органогенезу рослин;

Ютамі - ранньосередній гібрид зернового сорго, колір зерна - червоний, сприяв розмноженню кукурудзяного метелика;

Понкі - середній гібрид зернового сорго, колір зерна - молочний, практично не пошкоджувався гусеницями кукурудзяного метелика;

Майло - пізній гібрид зернового сорго, колір зерна - білий.

Сприяв порівняно високому рівню заселення сорго попелицями, що доцільно враховувати під час районування гібриду в Лісостепу України.

У вологі роки досліджень спостерігалась порівняно висока сезонна динаміка чисельності окремих фітофагів, зокрема заселення гібридів сорго злаковими попелицями. Переважаючим видом була звичайна злакова попелиця (Schisaphis graminum Rond). Попелиця пошкоджувала переважно листя, а у місцях живлення спостерігалось його почервоніння. У фазі цвітінні сорго, листя знебарвлювалось, плями зливались і листя засихало з верхівки. Характерно, що в разі сильного заселення сорго попелицями на стадії обгортки пошкоджені рослини можуть не викидати волоті $[4,6]$.

Встановлено, що ранньостиглі гібриди сорго заселялися попелицями в меншій кількості, в той час як пізнішого строку достигання заселені до $65 \%$, що свідчить про необхідність проведення захисних заходів у фазі 3-5 листків культури за появи нової генерації. Достовірний вплив на ступінь пошкодження сорго звичайною злаковою попелицею спостерігався в травні - початку червня, в порівняно жаркий період вегетації сорго. При цьому одним із чинників, що впливав на шкідливість фітофагів виявились порівняно стійкі гібриди Понкі та Майло. Доцільно відмітити, що у попелиць зимує переважно стадія яйця. Личинки відроджуються 3 яєць що перезимували зазвичай на початку або в середині травня. Наприкінці травня з'являються самкирозселювачки, 3 підвищенням середньодобової температури в колоніях переважають безкрилі самки. Найбільша чисельність шкідника спостерігається в кінці червня - липні $[3,6]$.

Рис. 1. Заселення гібридів сорго шкідниками по гібридам (у середньому за 2014-2016 рр.)

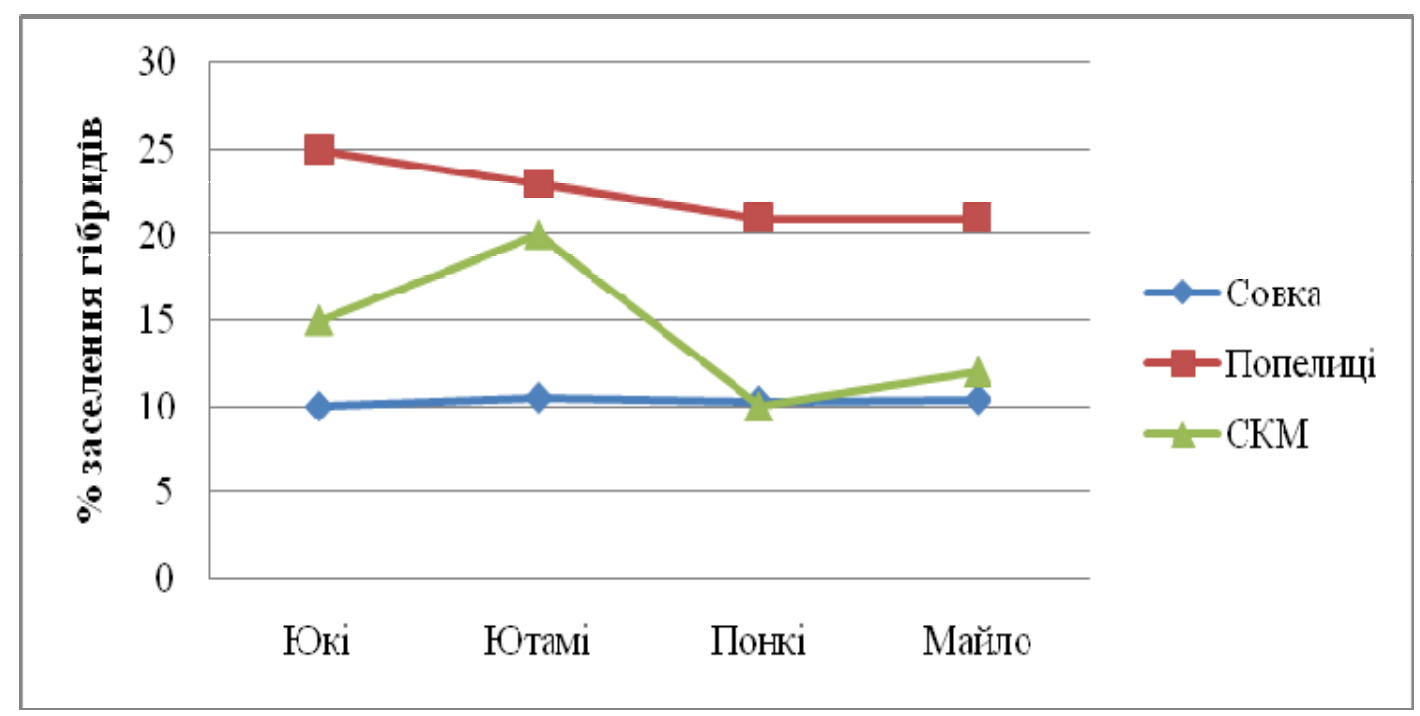




\section{1. Фенологія розвитку звичайної злакової попелиці на сорго}

(Інститут біоенергетичних культур і цукрових буряків НААНУ, 2015-2016 рр.)

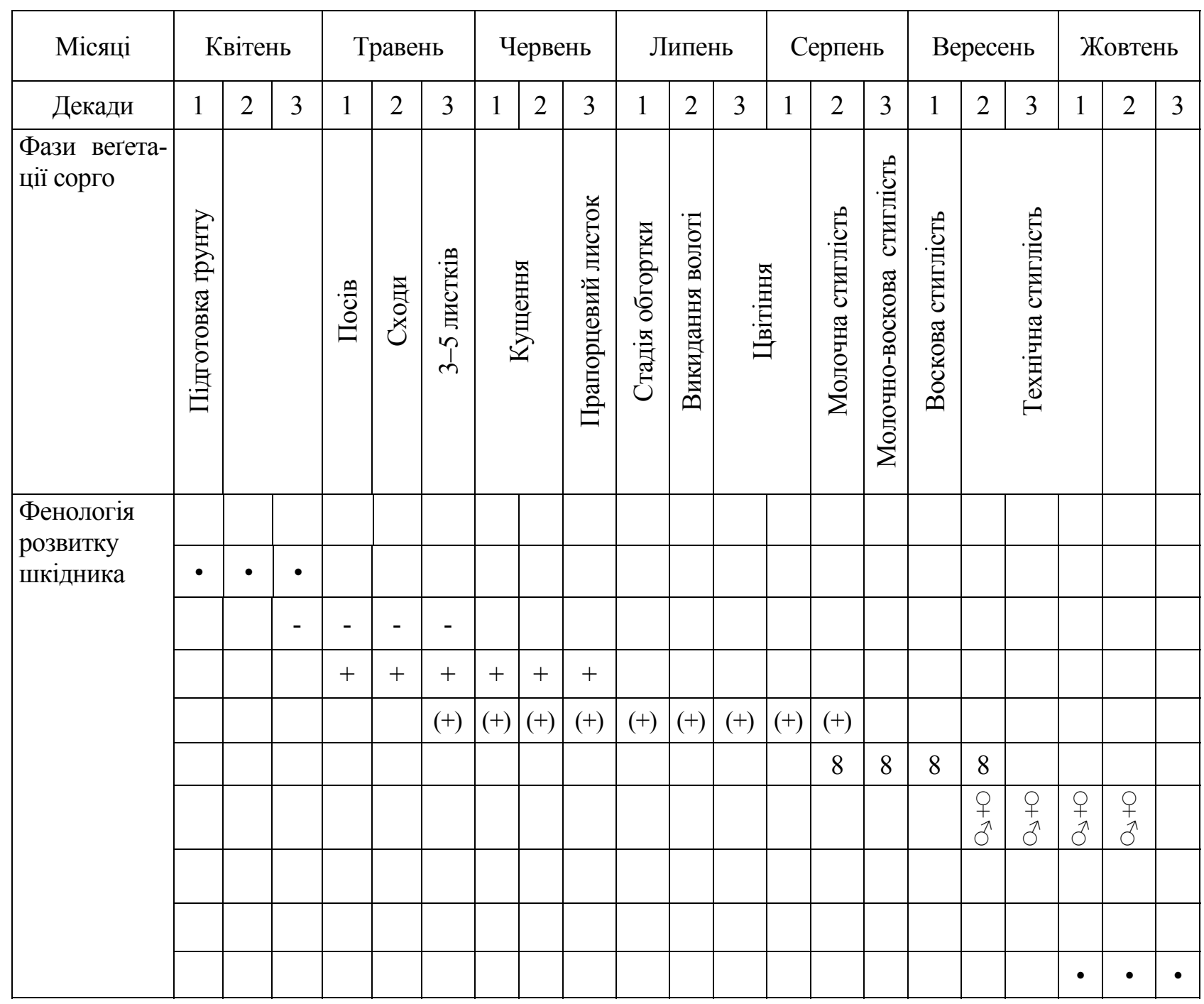

«๑» - яйце, «-» - личинка, «+» - самиця-засновниця, «(+)»- самиця-розселювачка, «8»- самиця-статеноска, «왜》- гамогенетичне покоління

Під час живлення звичайної злакової попелиці знижується не тільки урожай зерна, а і вихід зеленої маси, соломи, ріст коренів. Пошкодження звичайною злаковою попелицею викликає і якісні зміни в біохімічному складі рослин. Так, у результаті заселення модифікується метаболізм рослин: відбувається накопичення вільних амінокислот у пошкоджених листках, що зазвичай спостерігається у рослин, що передчасно засихали $[3,6,9]$.

Відомо, що попелиці є головними перенощиками вірусних хвороб рослин. Живлення комах на рослинах, заражених вірусною інфекцією, сприяє появі крилатих форм попелиці, що в свою чергу сприяє швидкому поширенню хвороб сорго. У хворих рослинах зазвичай зростає концентрація вільних амінокислот, що може сприяти більшій плодючості попелиць і появі крилатих особин. Значне пошкодження S. graminum нестійких гібридів сорго може сприяти поширенню і бактеріозів [6,8].

Встановлено, що найбільш вразлива фітофагами фаза сорго $є$ період від висіяного насіння до появи сходів. На цих етапах органогенезу особливу небезпеку становлять личинки озимої та інших видів підгризаючих совок.

Так, гусениці підгризаючих совок сприяють зменшенню густоти посіву, що свідчить про важливість обробки насіння системними інсектицидами. Нагальним $\epsilon$ i своєчасний контроль забур'яненості полів, що впливає на трофічні зв'язки шкідника 3 рослинами $[7,8]$. Характерно, що у поточному році спостерігалося 
підвищення шкідливості цих видів за умов, які склалися у попередньому вегетаційному сезоні.

Доцільно зазначити, що стан популяцій совок, або фаза багаторічної динаміки чисельності того чи іншого виду можна визначити за якісними показниками. Місцями кормові рослини сприяють розширенню ареалу і виживанню фітофагів сорго [9]. Ці трофічні особливості та розмноження озимої совки із обмеженням їі чисельності та шкідливості має важливе значення у застосуванні та ефективності організаційно-господарських й агротехнічних заходів, які є складовими технології отримання високих урожаїв сорго в Лісостепу України. Однак у періоди спалахів чисельності підгризаючих совок доцільно посилювати спостереження за їхнім розвитком та оцінювати ступінь загрози від них на кожному конкретному полі сівозміни. Нагальним $є$ i науково-обгрунтоване чергування культур у сівозміні, що дає змогу регулювати чисельність i поширення підгризаючих совок на сучасних гібридах сорго у різних грунтово-кліматичних зонах України.

У 2014-2016 рр. обліки чисельності стеблового кукурудзяного метелика проводили на досліджуваних гібридах сорго. На дослідних посівах відмічено щорічне зростання числа пошкоджень рослин сорго гусеницями стеблового кукурудзяного метелика (Ostrinia nubilalis Hb.).

Так, фенологія кукурудзяного метелика залежала від інтенсивності етапів органогенезу основної кормової культури. Самиці відкладали яйця на рослини сорго, які перебували головним чином у фазі виходу волоті $[3,4,10]$. При цьому перші години після відродження гусениці живились відкрито на поверхні рослин, пізніше вони проникають у центральну жилку листка, де живились і проходили стадії линьки. Через 14-18 діб вони мігрували всередину стебла. Оптимальними умовами розвитку для гусениць виявилась $17-35^{\circ} \mathrm{C}$ і вологість не нижче 70 \%. Для гусениць стеблового метелика характерна міграційна здатність (гусениці I-III віків) як в межах однієї рослини, так і з однієї рослини на іншу [7]. На сорго гусениці заселяли верхній ярус рослин, вище міжвузль, після викидання волоті мігрували всередині стебла в напрямку волоті, чим пошкоджували рослини та впливали на формування насіння. Під час пошкодження рослин, стебло зламувалось на рівні волоті. Це сприяло достовірному зменшенню врожаю пізньостиглих гібридів сорго.

\section{2. Фенологія розвитку озимої совки на сорго}

(Інститут біоенергетичних культур і цукрових буряків НААНУ, 2015-2016 рр.)

\begin{tabular}{|c|c|c|c|c|c|c|c|c|c|c|c|c|c|c|c|c|c|c|c|c|c|}
\hline Місяці & \multicolumn{3}{|c|}{ Квітень } & \multicolumn{3}{|c|}{ Травень } & \multicolumn{3}{|c|}{ Червень } & \multicolumn{3}{|c|}{ Липень } & \multicolumn{3}{|c|}{ Серпень } & \multicolumn{3}{|c|}{ Вересень } & \multicolumn{3}{|c|}{ Жовтень } \\
\hline Декади & 1 & 2 & 3 & 1 & 2 & 3 & 1 & 2 & 3 & 1 & 2 & 3 & 1 & 2 & 3 & 1 & 2 & 3 & 1 & 2 & 3 \\
\hline $\begin{array}{l}\text { Фази } \\
\text { вегетації } \\
\text { сорго }\end{array}$ & 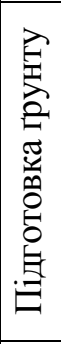 & & & $\begin{array}{l}. \frac{9}{8} \\
\text { 음 }\end{array}$ & 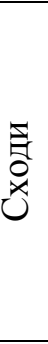 & 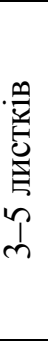 & 氛 & & 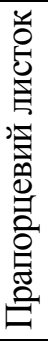 & 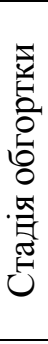 & 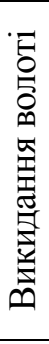 & . & & 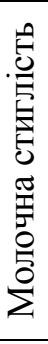 & 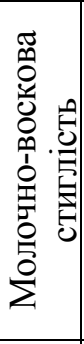 & 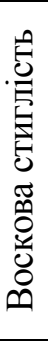 & \multicolumn{3}{|c|}{ 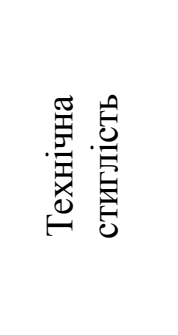 } & & \\
\hline \multirow{10}{*}{$\begin{array}{l}\text { Фенологія } \\
\text { розвитку } \\
\text { шкідника }\end{array}$} & \multicolumn{5}{|c|}{$0,5(0,7)$ екз. $/ \mathrm{M}^{2}$} & & & & & & & & & & & & & & & & \\
\hline & - & - & - & - & & & & & & & & & & & & & & & & & \\
\hline & & & 0 & 0 & 0 & 0 & & & & & & & & & & & & & & & \\
\hline & & & & & + & + & + & + & + & & & & & & & & & & & & \\
\hline & & & & & & • & • & $\bullet$ & • & & & & & & & & & & & & \\
\hline & & & & & & & - & - & - & - & - & & & & & & & & & & \\
\hline & & & & & & & & & & 0 & 0 & 0 & 0 & & & & & & & & \\
\hline & & & & & & & & & & & + & + & + & + & + & + & & & & & \\
\hline & & & & & & & & & & & & • & $\bullet$ & $\bullet$ & $\bullet$ & • & & & & & \\
\hline & & & & & & & & & & & & & - & - & - & - & - & - & - & - & - \\
\hline
\end{tabular}

Примітки: «-» - гусениця; «+» - імаго (метелик); «๑»-яйце, «0»- лялечка 
СТОРІНКА МОЛОДОГО ВЧЕНОГО

3. Фенологія розвитку стеблового (кукурудзяного) метелика на сорго

(Інститут біоенергетичних культур і иукрових буряків НААНУ, 2015-2016 рр.)

\begin{tabular}{|c|c|c|c|c|c|c|c|c|c|c|c|c|c|c|c|c|c|c|c|c|c|c|}
\hline Місяці & \multicolumn{3}{|c|}{ Квітень } & \multicolumn{3}{|c|}{ Травень } & \multicolumn{3}{|c|}{ Червень } & \multicolumn{4}{|c|}{ Липень } & \multicolumn{3}{|c|}{ Серпень } & \multicolumn{3}{|c|}{ Вересень } & \multicolumn{3}{|c|}{ Жовтень } \\
\hline Декади & 1 & 2 & 3 & 1 & 2 & 3 & 1 & 2 & 3 & 1 & 2 & & 3 & 1 & 2 & 3 & 1 & 2 & 3 & 1 & 2 & 3 \\
\hline \begin{tabular}{|l} 
Фази \\
вегетації \\
сорго
\end{tabular} & 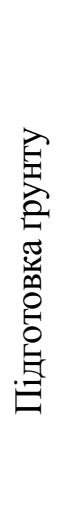 & & & $\begin{array}{l}. \frac{9}{0} \\
\text { 昌 }\end{array}$ & 泾 & 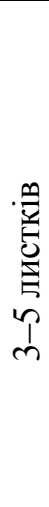 & & & 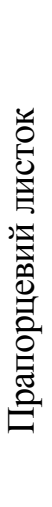 & 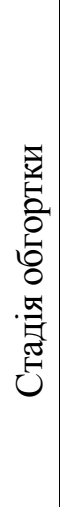 & 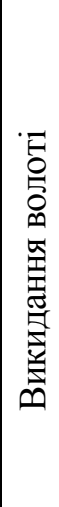 & & 鑒 & & 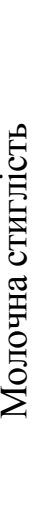 & 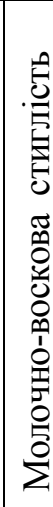 & 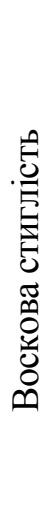 & & 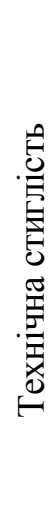 & & & \\
\hline \multirow{9}{*}{$\begin{array}{l}\text { Фенологія } \\
\text { розвитку } \\
\text { шкідника }\end{array}$} & - & - & - & - & - & - & - & - & - & - & & & & & & & & & & & & \\
\hline & & & & & & & & 0 & 0 & 0 & 0 & & & & & & & & & & & \\
\hline & & & & & & & & & + & + & + & + & & & & & & & & & & \\
\hline & & & & & & & & & & - & • & • & • & & & & & & & & & \\
\hline & & & & & & & & & & & & & - & . & 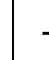 & - & & & & & & \\
\hline & & & & & & & & & & & & & & & 0 & 0 & 0 & 0 & & & & \\
\hline & & & & & & & & & & & & & & & & + & + & + & + & & & \\
\hline & & & & & & & & & & & & & & & & & $\bullet$ & $\bullet^{\bullet}$ & $\bullet$ & $\bullet$ & & \\
\hline & & & & & & & & & & & & & & & & & & - & - & - & - & \\
\hline
\end{tabular}

Доцільно зазначити, що шкідливість стеблового (кукурудзяного) метелика залежала від строків, ступеню i характеру пошкодження рослин. Окрім прямих втрат, стебловий метелик спричиняє підвищення ураження рослин хворобами $[4$, 9, 10]. Відмічено, що несприятливі абіотичні умови негативно впливали на розвиток і формування популяції кукурудзяного метелика, це доцільно розглядати як ефект, що не сприяв тривалій депресії і появі високої чисельності шкідника. Відмічено, що досліджені гібриди сорго відносно стійкі до кукурудзяного метелика, особливо у порівнянні з іншими фітоценозами, що пояснюється підвищеним вмістом глікозиду ДІМБОА в тканинах листя сорго [4]. У низці випадків це знижує привабливість рослин, в інших - робить їх менш придатними для живлення i розвитку личинок шкідника, знижує рівень шкоди і погіршує фізіологічні показники фітофага, особливо в порівнянні з популяціями, які формуються в посівах кукурудзи.

Висновок. У 2014-2016 pp. розвиток, розмноження та поширення фітофагів і їх шкідливість на сорго залежала від комплексу факторів зовнішнього середовища, зокрема від чинників, що впливають на фенологію шкідників сорго. В роки досліджень сорго заселялося як грунтовими, так і аерогенними видами шкідників, що спостерігалися на основних фазах розвитку сорго.

Порівняно стійкими гібридами сорго до основних шкідливих видів комах виявились Понкі та Майло, що доцільно враховувати в сучасних формах ведення господарств у Лісостепу України. 


\section{БІБЛІОГРАФІЯ}

1. Доля М. М. Фітосанітарний моніторинг : посібник для студ. агроном. спец. вищих закл. аграрної освіти III-IV рівнів акредитації / М. М. Доля ; ред. М. М. Доля, Й. Т. Покозій. - К. : Національний аграрний ун-т : ННЦ IAE, 2004. $294 \mathrm{c}$.

2. Олексенко Ю. Ф. Приемы основной обработки почвы под сахарное сорго / Ю. Ф. Олексенко, С. И. Жученко, С. В. Красненков // Бюллетень ВНИИ кукурузы. - Днепропетровск. 1986. - №64. - С. 71-75.

3. Кулаков Е. П. Вредители сорго и меры борьбы с ними (обзор) / Е. П. Кулаков // Сельское х-во за рубежом, 1977. - 4. - С. 26-28.

4. Фролов А. Н. Кукурузный мотылек на сорго в Краснодарском крае / А. Н. Фролов, К. Д. Дятлова, Н. В. Андрияш // Кукуруза и сорго, 1995. 2. - C. 5 .

5. Шепель М. А. Сорго - інтенсивна культура / М. А. Шепель. - Симферополь : Таврия, 1989. 192 c.

6. Якушев Б. С., Добрякова Е. П. Некоторые особенности биологии обыкновенной злаковой тли на сорго в Саратовской области / Якушев Б. С.,
Добрякова Е. П. // Защита растений от вредителей и болезней на юго-востоке и в западном Казахстане. - Саратов. - 1980. - С. 3-7.

7. Buntin G. Grain sorghum insect pests and their management / G. Buntin. - University of Georgia Extension, 2012.

8. Hackerott H. L. Greenbug resistance in sorghums / H. L. Hackerott, T. L. Harvey, W. M. Ross // Crop Sci. 1969. - V. 9. - №5. - P. 656-658.

9. Pitre H. N. INTSORMIL: Two decades of entomological research for improved crop production / H. N. Pitre, G. L. Teetes, G. C. Peterson. - Baltimore, MD. Agron. Abstr. - Oct. 18-22, 1998. P. 45.

10. Pendleton Bonnie B. Integrated crop management in sorghum: comprehensive manual and model / Bonnie B. Pendleton, Richard A. Frederiksen, George L. Teetes. - 1997. - P. 665-666. - [In. Rosenow et al (eds)] : Proc. of International Conference on Genetic Improvement of Sorghum and Pearl Millet, 22-27 September 1996. - Lubbock, TX. INTSORMIL, University of Nebraska, Lincoln, NE. Publ. 97-5. 